\title{
Molybdenum Effects on Pitting Corrosion Resistance of FeCrMnMoNC Austenitic Stainless Steels
}

\author{
Heon-Young $\mathrm{Ha}^{1}{ }^{1} * \mathbb{D}$, Tae-Ho Lee ${ }^{1}$, Jee-Hwan Bae ${ }^{2}$ and Dong Won Chun ${ }^{2}$ \\ 1 Steel Department, Korea Institute of Materials Science, 797 Changwondae-ro, Seongsan-gu, Changwon, \\ Gyeongnam 51508, Korea; 1th@kims.re.kr \\ 2 Advanced Analysis Center, Korea Institute of Science and Technology, 5, Hwarang-ro 14-gil, Seongbuk-gu, \\ Seoul 02792, Korea; jeehwani@kist.re.kr (J.-H.B.); chundream98@kist.re.kr (D.W.C.) \\ * Correspondence: hyha2007@kims.re.kr; Tel.: +82-55-280-3422; Fax: +82-55-280-3599
}

Received: 18 July 2018; Accepted: 16 August 2018; Published: 20 August 2018

check for updates

\begin{abstract}
For Fe-based 18Cr10Mn0.4N0.5C(0-2.17)Mo (in wt \%) austenitic stainless steels, effects of Mo on pitting corrosion resistance and the improvement mechanism were investigated. Alloying Mo increased pitting and repassivation potentials and enhanced the passive film resistance by decreasing number of point defects in the film. In addition, Mo reduced critical dissolution rate of the alloys in acidified chloride solutions, and the alloy with higher Mo content could remain in the passive state in stronger acid. Thus, it was concluded that the alloying Mo enhanced pitting corrosion resistance of the alloys through increasing protectiveness of passive film and lowering pit growth rate.
\end{abstract}

Keywords: high interstitial alloy; molybdenum; pitting corrosion; passive film

\section{Introduction}

FeCrMnNC austenitic stainless steels known as high interstitial alloys (HIAs) are attractive and economical materials to replace conventional FeCrNi austenitic stainless steels [1-10]. The main purpose of using $\mathrm{C}, \mathrm{N}$, and $\mathrm{Mn}$ for HIA is to stabilize the austenite phase instead of Ni being an expensive austenite stabilizer $[1,2,4,11]$. In addition, alloying $C$ and $N$ in stainless steels imparts improved mechanical properties including strength and wear resistance. Regarding corrosion properties, the fact that the alloying $\mathrm{N}$ improves the resistance to localized corrosion of stainless steels is well known [12,13], and C in solid solution state is also reported to be advantageous to enhance the pitting corrosion resistance $[1,5,6,10,14,15]$. Thus, new FeCrMnNC alloys have been explored, with comparable and/or superior performances including strength, elongation, and corrosion resistance to the conventional FeCrNi austenite stainless steels; hence, various types of HIAs have been designed and investigated [1-3,5,8,9]. The author group has made an effort to develop new HIAs with high $\mathrm{C}$ and $\mathrm{N}$ contents $(\mathrm{C}>0.3 \mathrm{wt} \%$ and $\mathrm{N}>0.3 \mathrm{wt} \%)$, and we have found that the Fe-based $18 \mathrm{Cr} 10 \mathrm{Mn} 0.4 \mathrm{~N}(0.3-0.5) \mathrm{C}$ (in wt \%) alloys exhibit desirable performances [5-7,14]. The alloys have subsequently been modified with various alloying elements such as $\mathrm{Mo}, \mathrm{Ni}, \mathrm{Cu}, \mathrm{Nb}$, and $\mathrm{W}$ in order to further improve their mechanical and corrosion properties. Consequently, it has been revealed that the Fe-based 18Cr10Mn0.4N0.5C (in wt \%) HIAs with small amount of Mo, Ni, and W (less than $2 \mathrm{wt} \%$ ) have mechanical properties and resistance to localized corrosion superior to the UNS S30400 and UNS S31603 stainless steels $[16,17]$.

One of the recommended methods to improve the resistance to localized corrosion of stainless steels, including HIAs, is alloying Mo [18-22]. Although Mo is an expensive ferrite former and is able to form a brittle $\sigma$ phase, which leads to degradation of the physico-chemical properties of stainless steels [23-25], a small amount of Mo (2-4 wt \%, sometimes up to $6 \mathrm{wt} \%)$ is frequently used in conventional austenitic stainless steels because of its definite advantages to the localized 
corrosion resistance. Lots of investigations on the mechanism of improved resistance to localized corrosion by Mo addition have been performed [20-22,26-35]. The desirable localized corrosion resistance of Mo-bearing stainless steels is attributed to various factors. Mo is known to promote the protectiveness of the passive film by formation of the Mo- $[26,27,36]$ and/or Cr-enriched [30,37] film and by thickening of the passive film [26]. Mo is also reported to be beneficial to enhance repassivation characteristics [22]. In addition, it is suggested that molybdate ion $\left(\mathrm{MoO}_{4}{ }^{2-}\right)$ is formed during dissolution of Mo-bearing metal, which effectively blocks the adsorption of chloride ion $\left(\mathrm{Cl}^{-}\right)[26,29,33]$. The positive influences of Mo on pitting corrosion behavior have been observed in various types of stainless steels, including FeCr-based ferritic stainless steels $[22,27,29,30,33,36]$, FeCrNi-based austenitic stainless steels [22,26,30,35,36], FeCrMnN-based high-nitrogen stainless steels [35], and FeCrNiMo-based duplex stainless steels [36,38,39]. However, Sugimoto [26] reported that the alloying Mo was ineffective to improve the pitting corrosion resistance of FeMo and NiMo binary alloys, and Kaneko [22] reported that the positive effect of Mo was pronounced in FeCrNi austenitic stainless steel in comparison with FeCr ferritic stainless steel. In addition, it is worth mentioning that the beneficial effect of Mo is manifested in the presence of $\mathrm{Cr}$ in Fe-based alloys, and Mo exhibits synergistic effects on the corrosion resistance when alloyed with $\mathrm{N}$ in stainless steels $[35,39]$. These observations suggest that the influence of Mo changes depending on the matrix composition, and thus it is worth investigating the Mo effect on the localized corrosion behavior and passivity of newly developed HIAs. Therefore, the objectives of this paper are to investigate the effects of Mo on the resistance to pitting corrosion of Fe-based 18Cr10Mn0.4N0.5C(0-2.17)Mo (in wt \%) austenite stainless steels, and to find the reasons for the change in the pitting corrosion resistance.

\section{Experimental Section}

\subsection{Materials and Mechanical Tests}

The investigated alloys were Fe-based 18Cr10Mn0.4N0.5C(0-2.17)Mo (in wt \%) HIAs, which have been patented recently $[16,17]$. The detailed chemical compositions of the three alloys are given in Table 1, and were measured using an optical emission spectroscopy (QSN 750-II, PANalytical, Almemo, The Netherlands) and an inductively coupled plasma atomic emission spectroscopy (Optima 8300DV, PerkinElmer, Waltham, MA, USA).

Table 1. Chemical compositions (in wt \%) and mechanical properties of the investigated alloys.

\begin{tabular}{cccccccccc}
\hline Alloys & Fe & Cr & Mn & Mo & N & C & $\begin{array}{c}\text { Yield Strength } \\
\text { (MPa) }\end{array}$ & $\begin{array}{c}\text { Tensile Strength } \\
\text { (MPa) }\end{array}$ & $\begin{array}{c}\text { Elongation } \\
\text { (\%) }\end{array}$ \\
\hline 0Mo & & 18.19 & 9.72 & - & 0.36 & 0.50 & 502.1 & 957.2 & 61.7 \\
1Mo & Balance & 17.89 & 9.81 & 1.13 & 0.40 & 0.47 & 499.2 & 897.5 & 56.4 \\
2Mo & & 18.10 & 9.47 & 2.17 & 0.38 & 0.48 & 529.0 & 979.9 & 62.1 \\
\hline
\end{tabular}

The alloy ingots $\left(10 \mathrm{~kg}\right.$ ) were produced by vacuum induction melting under $\mathrm{N}_{2}$ atmosphere. The ingots were homogenized at $1250{ }^{\circ} \mathrm{C}$ for $1 \mathrm{~h}$ under Ar atmosphere. After the homogenization, the ingots were hot-rolled from $40 \mathrm{~mm}$ (initial thickness) to $4 \mathrm{~mm}$ (final thickness), followed by water quenching. The hot-rolled plates were then solutionized at $1200{ }^{\circ} \mathrm{C}$ for $30 \mathrm{~min}$ and quenched in water. The temperatures for the thermomechanical processes were determined from equilibrium phase diagrams (Thermo-Calc software version 4.1, TCFE 7.0 database, Solna, Sweden) shown in Figure 1. 

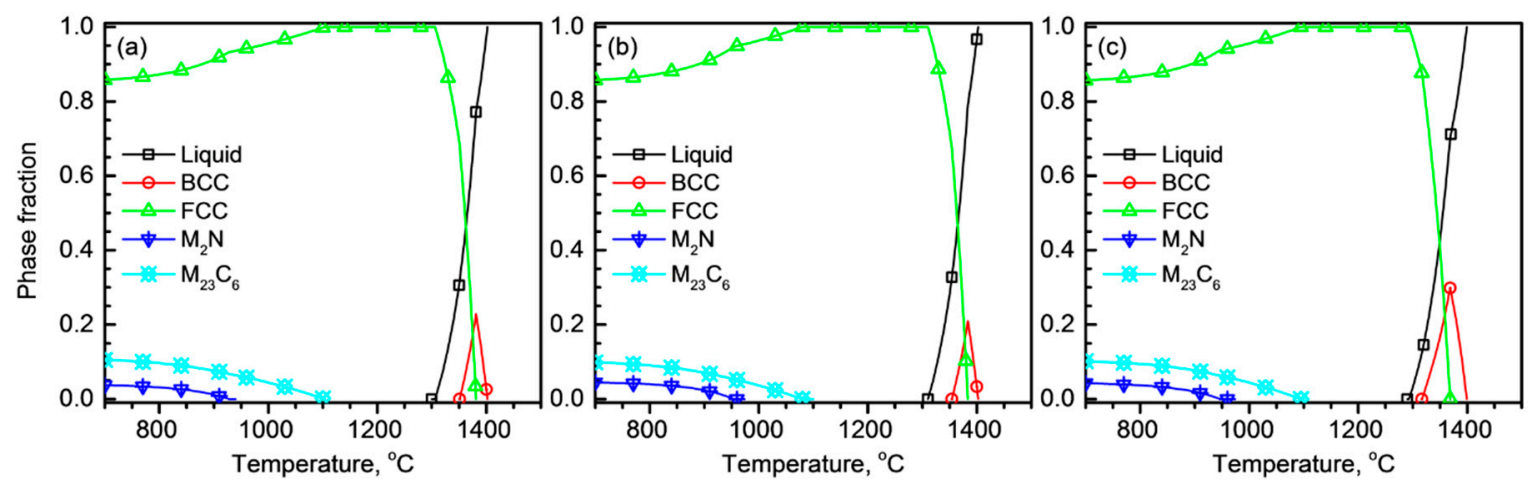

Figure 1. Phase fractions of (a) $0 \mathrm{Mo},(\mathbf{b}) 1 \mathrm{Mo}$, and (c) $2 \mathrm{Mo}$ alloys as a function of temperature calculated using Thermo-Calc software.

Then the microstructures of the alloys were examined. Specimens $(15 \mathrm{~mm} \times 10 \mathrm{~mm} \times 4 \mathrm{~mm})$ were cropped from the solutionized plates, mechanically polished using a diamond suspension with a particle size of $1 \mu \mathrm{m}$, and chemically etched in acid solution $\left(20 \mathrm{~mL} \mathrm{HNO}_{3}+30 \mathrm{~mL} \mathrm{HCl}+50 \mathrm{~mL}\right.$ distilled water) for 1-3 min. A scanning electron microscope (SEM, JSM-5800, JEOL, Tokyo, Japan) was employed to observe the microstructure. The strength and elongation values were measured by tensile tests at $25^{\circ} \mathrm{C}$ with a nominal strain rate of $1.67 \times 10^{-3} / \mathrm{s}$ using a servohydraulic machine (INSTRON 5882, Norwood, MA, USA) on tensile specimens (ASTM E8M).

\subsection{Electrochemical Tests}

The resistance to pitting corrosion of the 0Mo-2Mo alloys was compared with that of S30400 (Fe-based 18.5Cr8.2Ni1.0Mn0.6Si0.04C, in wt \%) and S31603 (Fe-based 17.4Cr12.0Ni2.4Mo1.0Mn0.5Si0.02C, in wt \%) alloys by linear potentiodynamic polarization tests in a $1 \mathrm{M} \mathrm{NaCl}$ solution at $25^{\circ} \mathrm{C}$ with a potential sweep rate of $1 \mathrm{mV} / \mathrm{s}$. Then in order to assess the pitting corrosion resistance of $0 \mathrm{Mo}, 1 \mathrm{Mo}$, and $2 \mathrm{Mo}$ alloys more clearly, linear and cyclic potentiodynamic polarization tests were performed in various aqueous solutions containing $4 \mathrm{M} \mathrm{NaCl}(4 \mathrm{M} \mathrm{NaCl}$, buffered $4 \mathrm{M} \mathrm{NaCl}$, and acidified $4 \mathrm{M} \mathrm{NaCl}$ solutions) at $25^{\circ} \mathrm{C}$. The buffer solution was borate-phosphate-citric buffer at $\mathrm{pH} 8.5$ with a composition of $0.2 \mathrm{M}$ boric acid $+0.05 \mathrm{M}$ citric acid $+0.1 \mathrm{M}$ tertiary sodium phosphate. The acidified $\mathrm{NaCl}$ solutions were $4 \mathrm{M} \mathrm{NaCl}$ with (0.00043-0.1) $\mathrm{M} \mathrm{HCl}$ solutions, in which both localized and general corrosion behavior could be simultaneously evaluated. The linear polarization was conducted from $-0.1 \mathrm{~V}$ versus corrosion potential $\left(E_{c o r r}\right)$ to pitting potential $\left(E_{\text {pit }}\right)$ at a potential sweep rate $(\mathrm{d} V / \mathrm{d} t)$ of $1 \mathrm{mV} / \mathrm{s}$. For the cyclic polarization tests, the potential was elevated from $-0.1 \mathrm{~V}$ versus $E_{\text {corr }}$ to the potential value at which the current density exceeded $0.1 \mathrm{~mA} / \mathrm{cm}^{2}$, and then lowered to the repassivation potential $\left(E_{r p}\right)$ with a $\mathrm{d} V / \mathrm{d} t$ of $1 \mathrm{mV} / \mathrm{s}$.

The passive behavior and electronic properties of the passive film were investigated in the borate-phosphate-citric buffer solution $(\mathrm{pH} 8.5)$ without $\mathrm{NaCl}$. Passive potential range and passive current density $\left(i_{\text {passive }}\right)$ were examined through potentiodynamic polarization tests in the buffer solution at $25^{\circ} \mathrm{C}$ with a $\mathrm{d} V / \mathrm{d} t$ of $1 \mathrm{mV} / \mathrm{s}$, and the resistance of the passive film was investigated by measuring the real part of the impedance $\left(Z^{\prime}\right.$ real $)$ during the anodic polarization [35,40-43]. The $Z^{\prime}$ real values of the passive films were measured by imposing sine-wave voltage perturbation $( \pm 10 \mathrm{mV})$ at a frequency of $0.1 \mathrm{~Hz}[40,41]$ during increase in the applied potential from -0.8 to $0.9 \mathrm{~V}_{\mathrm{SCE}}$. Then the point defect density in the space charge layer of the passive film was measured through Mott-Schottky analysis. For the test, the passive film was formed by applying constant anodic potential of $0.85 \mathrm{~V}_{\mathrm{SCE}}$ for $3 \mathrm{~h}$ in the buffer solution, and then the capacitance of the passivated layer was measured by imposing sine-wave voltage perturbation $( \pm 10 \mathrm{mV})$ at a frequency of $1000 \mathrm{~Hz}$ during the negative (cathodic) potential sweep from 0.85 to $-0.7 \mathrm{~V}_{\mathrm{SCE}}$. 
The electrochemical tests were controlled by a potentiostat (Reference 600, GAMRY Instruments, Warminster, PA, USA), and performed in a multineck flask (1 L) with three electrodes; a specimen as a working electrode, a Pt plate $(50 \mathrm{~mm} \times 120 \mathrm{~mm} \times 0.1 \mathrm{~mm})$ as a counter electrode, and a saturated calomel reference electrode (SCE) as a reference electrode. For the working electrode, specimens $(10 \mathrm{~mm} \times 10 \mathrm{~mm} \times 4 \mathrm{~mm})$ were mounted in cold epoxy resin and ground using SiC emery paper up to 2000 grit. The exposed area for the electrochemical tests was $0.2 \mathrm{~cm}^{2}$, which was controlled using electroplating tape. For each specimen, the polarization tests were conducted 5-6 times, and the resistance and capacitance of the passive layer were measured $4-5$ times in order to confirm reproducibility.

\section{Results and Discussion}

\subsection{Microstructure and Tensile Properties}

Figure 2a-c exhibits SEM images of the 0Mo, 1Mo, and 2Mo alloys, respectively, after solutionization at $1200^{\circ} \mathrm{C}$ for $30 \mathrm{~min}$ followed by water quenching. The concentrations of the interstitial alloying elements $(\mathrm{C}+\mathrm{N})$ of the alloys were as high as $0.86-0.87 \mathrm{wt} \%$, thus the solution treatment should be conducted at a high temperature range of between 1100 and $1250^{\circ} \mathrm{C}$ to suppress the formation of $\mathrm{M}_{23} \mathrm{C}_{6}$ and / or $\mathrm{M}_{2} \mathrm{~N}$ ( $\mathrm{M}$ stands for metal, primarily $\mathrm{Cr}$ ) as indicated in Figure 1. As shown in Figure 2, the three alloys have an austenite single phase with annealing twins and $\mathrm{M}_{23} \mathrm{C}_{6}$ and/or $\mathrm{M}_{2} \mathrm{~N}$ are not formed even at the grain boundaries. In addition, nonmetallic inclusions such as Mn-oxide and Mn-sulfide are rarely observed in the alloys. Using SEM images taken at 5-6 different locations, the average grain sizes of the samples were measured in accordance with ASTM E112; as a result, the average grain sizes of $0 \mathrm{Mo}, 1 \mathrm{Mo}$, and $2 \mathrm{Mo}$ alloys were $150.2,148.8$, and $142.4 \mu \mathrm{m}$, respectively, suggesting that the addition of Mo did not have a significant influence on the grain size.
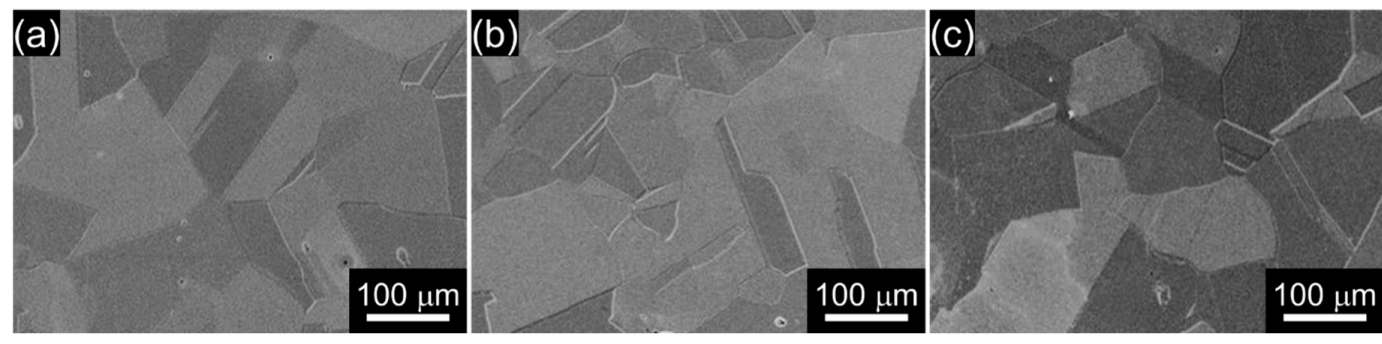

Figure 2. Microstructures of (a) 0Mo, (b) $1 \mathrm{Mo}$, and (c) 2Mo alloys (SEM).

The tensile properties of the three alloys are summarized in Table 1 . The $0 \mathrm{Mo}-2 \mathrm{Mo}$ alloys exhibit yield strength of 499.2-529.0 MPa, tensile strength of 897.5-979.9 MPa, and elongation of 56.4-62.1\%. The 2Mo alloy exhibits the best tensile properties among the three alloys. It is worth mentioning that the investigated alloys have better mechanical properties than the commercial austenitic stainless steels. It is reported that the S31603, for example, has yield strength, tensile strength, and elongation values of $170 \mathrm{MPa}, 485 \mathrm{MPa}$ and $40 \%$, respectively [44].

\subsection{Pitting Corrosion Resistance}

Resistance to pitting corrosion of the investigated alloys was compared with the commercial austenitic stainless steels, S30400 and S31603. Figure 3 shows the polarization curves of the alloys measured in a $1 \mathrm{M} \mathrm{NaCl}$ solution at $25^{\circ} \mathrm{C}$. The five alloys exhibit passive behavior in the potential range from $E_{\text {corr }}$ to $E_{\text {pit }}$. The $E_{\text {pit }}$ values of $\mathrm{S} 30400$ and $\mathrm{S} 31603$ alloys were 0.294 and $0.470 \mathrm{~V}_{\mathrm{SCE}}$, respectively, and those of $0 \mathrm{Mo}$ and $1 \mathrm{Mo}$ alloys were $0.390 \mathrm{~V}_{\mathrm{SCE}}$ and $0.643 \mathrm{~V}_{\mathrm{SCE}}$, respectively. The pitting corrosion did not occur in the $2 \mathrm{Mo}$ alloy. Figure 3 demonstrates that the resistance to pitting corrosion increased in the order, $\mathrm{S} 30400<0 \mathrm{Mo}<\mathrm{S} 31603<1 \mathrm{Mo}<2 \mathrm{Mo}$. It is obvious that the $1 \mathrm{Mo}$ and $2 \mathrm{Mo}$ exhibit superior corrosion resistance to the S31603, and even 0Mo has better resistance than S30400. Figure 3 confirms the excellent anti-corrosion properties of developed FeCrMnMoNC alloys. 


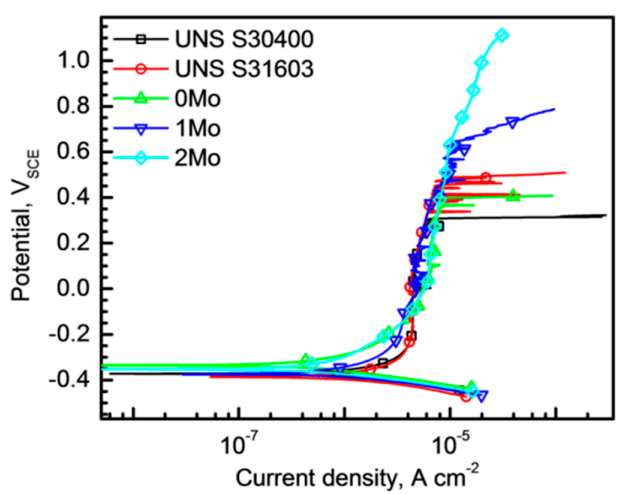

Figure 3. Linear potentiodynamic polarization curves of 0Mo, 1Mo, and 2Mo alloys and UNS S30400 and UNS S31603 alloys measured in $1 \mathrm{M} \mathrm{NaCl}$ solution at $25^{\circ} \mathrm{C}(\mathrm{d} V / \mathrm{d} t=1 \mathrm{mV} / \mathrm{s})$.

The pitting corrosion resistance of the $0 \mathrm{Mo}, 1 \mathrm{Mo}$, and $2 \mathrm{Mo}$ alloys was evaluated more clearly. Figure $4 \mathrm{a}$ shows cyclic potentiodynamic polarization curves of $0 \mathrm{Mo}, 1 \mathrm{Mo}$, and $2 \mathrm{Mo}$ alloys measured in a $4 \mathrm{M} \mathrm{NaCl}$ solution at $25^{\circ} \mathrm{C}$. The $E_{\text {corr }}$ value of $0 \mathrm{Mo}$ alloy was $-0.399 \mathrm{~V}_{\mathrm{SCE}}$ and it slightly increased to $-0.321 \mathrm{~V}_{\mathrm{SCE}}$ for $2 \mathrm{Mo}$ alloy. The alloys were in a passive state under open circuit conditions in this solution, and the passivity appeared in a limited potential range from the $E_{c o r r}$ to the $E_{\text {pit }}$, at which an abrupt and irreversible increase in the current density began. The average $E_{p i t}$ and $E_{r p}$ values obtained from the repetitive polarization tests (5-6 times) in the $4 \mathrm{M} \mathrm{NaCl}$ solution were plotted versus the Mo content in Figure $4 \mathrm{~b}$. The average $E_{\text {pit }}$ increased linearly from 0.213 to $0.940 \mathrm{~V}_{\mathrm{SCE}}$ with an increase in the Mo content from 0 to $2.17 \mathrm{wt} \%$, indicating the improved pitting corrosion resistance of the HIAs by alloying Mo. The $E_{r p}$ is also shifted to a higher value as the Mo content increases. For 0Mo alloy, the stable pit can repassivate below $-0.344 \mathrm{~V}_{\mathrm{SCE}}$, which is close to its $E_{c o r r}$ value, while the average $E_{r p}$ of $2 \mathrm{Mo}$ alloy is $0.840 \mathrm{~V}_{\mathrm{SCE}}$. It is worth mentioning that the difference between the $E_{p i t}$ and $E_{r p}$ values, $\Delta\left(E_{p i t}-E_{r p}\right)$ significantly decreases from 0.557 to $0.099 \mathrm{~V}$ as the Mo content increases.
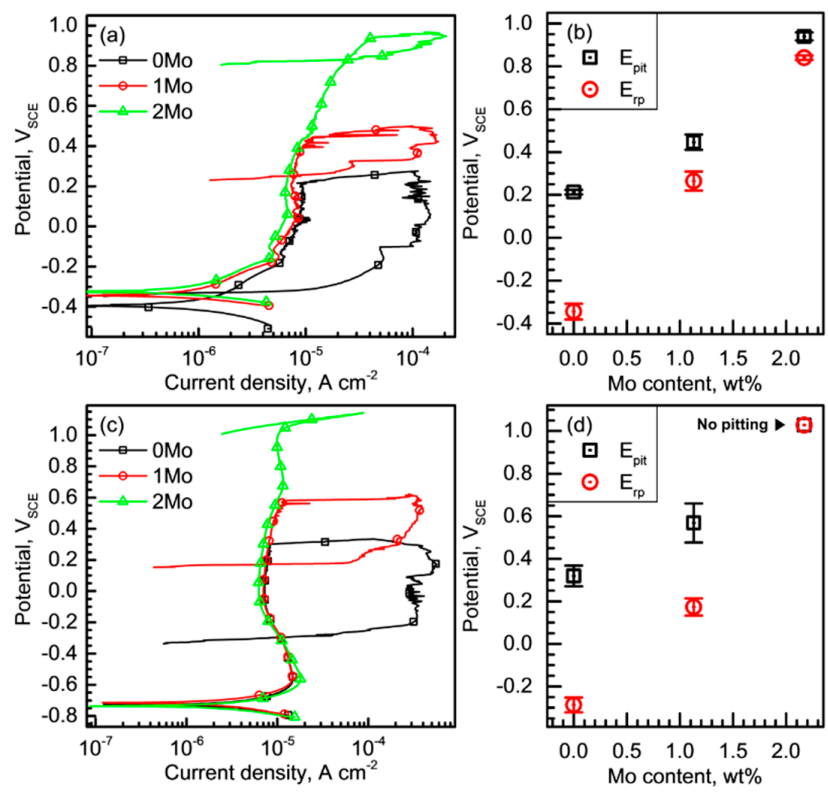

Figure 4. Cyclic potentiodynamic polarization curves of $0 \mathrm{Mo}, 1 \mathrm{Mo}$, and $2 \mathrm{Mo}$ alloys measured in (a) $4 \mathrm{M} \mathrm{NaCl}$ and (c) borate-phosphate-citric buffer containing $4 \mathrm{M} \mathrm{NaCl}(\mathrm{pH} 8.5)$ solutions at $25^{\circ} \mathrm{C}$. $(\mathrm{d} V / \mathrm{d} t=1 \mathrm{mV} / \mathrm{s})$. Average pitting and repassivation potentials with standard deviation values (scatter band) of the alloys measured in (b) $4 \mathrm{M} \mathrm{NaCl}$ and (d) buffered $4 \mathrm{M} \mathrm{NaCl}$ solutions. 
The polarization curves in Figure 4a show changes in other features by addition of Mo, such as $i_{\text {passive }}$ and number of metastable pitting corrosion events. The lowest $i_{\text {passive }}$ value is observed in the 2Mo alloy in the entire potential range, and the $i_{\text {passive }}$ decreases from 8.3 to $5.8 \mu \mathrm{A} / \mathrm{cm}^{2}$ (at $0 \mathrm{~V}_{\mathrm{SCE}}$, for example) as the Mo content increases. Moreover, small current spikes indicating the initiation and repassivation of metastable pits are more frequently observed in the polarization curve of the alloys with lower Mo content.

Figure $4 \mathrm{c}$ exhibits the cyclic potentiodynamic polarization curves of the alloys measured in a borate-phosphate-citric buffer solution ( $\mathrm{pH}$ 8.5) with $4 \mathrm{M} \mathrm{NaCl}$ at $25^{\circ} \mathrm{C}$. In this solution, the $E_{\text {corr }}$ of the alloys was approximately $-0.73 \mathrm{~V}_{\mathrm{SCE}}$. The alloys also exhibited passivity at $E_{\text {corr }}$, and pitting corrosion occurred under sufficient anodic polarization, except for the $2 \mathrm{Mo}$ alloy. The average $E_{\text {pit }}$ values of $0 \mathrm{Mo}$ and $1 \mathrm{Mo}$ alloys were 0.319 and $0.568 \mathrm{~V}_{\mathrm{SCE}}$, respectively, and the $E_{r p}$ of $0 \mathrm{Mo}$ alloy was $-0.287 \mathrm{~V}_{\mathrm{SCE}}$ and that of $1 \mathrm{Mo}$ alloy was $0.173 \mathrm{~V}_{\mathrm{SCE}}$. Figure $4 \mathrm{~d}$ confirms again that the alloying Mo raises both $E_{\text {pit }}$ and $E_{r p}$. Moreover, the $\Delta\left(E_{p i t}-E_{r p}\right)$ also decreases from 0.606 to $0.395 \mathrm{~V}_{\mathrm{SCE}}$ as the Mo content increased from 0 to $1.13 \mathrm{wt} \%$.

The $E_{\text {pit }}$ values obtained in the buffered $\mathrm{NaCl}$ solution (Figure $4 \mathrm{~d}$ ) were higher than those obtained in the simple $\mathrm{NaCl}$ solution (Figure $4 \mathrm{~b}$ ). Besides, comparing the polarization curves measured in the buffered and simple $\mathrm{NaCl}$ solutions, it was found that the occurrence of metastable pitting corrosion during the polarization was restrained in the buffered $\mathrm{NaCl}$ solution. The better resistance to pitting corrosion obtained in the buffer solution is considered to be due to two possible reasons. First, anions in the borate-phosphate-citric buffer solution, $\mathrm{H}_{2} \mathrm{BO}_{3}{ }^{-}, \mathrm{H}_{2} \mathrm{PO}_{4}{ }^{-}$, and $\mathrm{H}_{2} \mathrm{C}_{6} \mathrm{H}_{5} \mathrm{O}_{7}{ }^{-}$, act as inhibitors to adsorption of $\mathrm{Cl}^{-}$on the passivated electrode, and second, the buffer solution containing the anions is helpful to form protective passive film as reported [40,45].

It is obvious from Figure 4 that the alloying Mo enhances the resistance to pitting corrosion of the Fe-based $18 \mathrm{Cr} 10 \mathrm{Mn} 0.4 \mathrm{~N} 0.5 \mathrm{C}(0-2.17) \mathrm{Mo}$ (in wt \%) HIAs. More specifically, alloying Mo improves the resistance to pit initiation, which is supported by the decrease in the number of metastable pitting corrosion events, and accelerates repassivation kinetics, which is proven by the rise in the $E_{r p}$; thus, the Mo alloying consequently shifts the $E_{p i t}$ to the higher level. Moreover, it is considered that the decrease in the $\Delta\left(E_{p i t}-E_{r p}\right)$ value along with increase in the Mo alloying demonstrates that the alloying Mo is more effective in accelerating repassivation kinetics than the pit initiation probability, which is related to the passive film protectiveness. Thus, in order to explain the role of Mo alloying in the improvement of resistance to stable pitting corrosion, passive and general corrosion behavior of the three HIAs was investigated. The former is correlated with the pit initiation probability and the latter is related to the pit growth rate [41].

\subsection{Passive Behavior}

The passive behavior and passive film properties were investigated. For this, a borate-phosphatecitric buffer solution ( $\mathrm{pH} 8.5$ ) without $\mathrm{NaCl}$ was used because a thick and protective passive film can be formed on Fe-based alloys in this solution, as reported [40,45]. The passive behavior of the alloy in the buffer solution was examined through potentiodynamic polarization tests (Figure 5a). In this mild basic buffer solution, the polarization curves of the three alloys are almost identical in shape, and the passivity was observed in the potential range from $E_{\text {corr }}$ (approximately $-0.82 \mathrm{~V}_{\mathrm{SCE}}$ ) to transpassive potential (approximately $0.95 \mathrm{~V}_{\mathrm{SCE}}$ ), where the oxygen evolution began. In the passive potential range, three current peaks are observed at $-0.66,-0.47$, and $0.64 \mathrm{~V}_{\mathrm{SCE}}$, respectively. It is known that the first current peak at $-0.66 \mathrm{~V}_{\mathrm{SCE}}$ is due to the oxidation of $\mathrm{Fe}$ to $\mathrm{Fe}^{2+}$, and the second current peak at $-0.47 \mathrm{~V}_{\mathrm{SCE}}$ is attributed to re-oxidation of $\mathrm{Fe}^{2+}$ to $\mathrm{Fe}^{3+}$. The third current peak at $0.64 \mathrm{~V}_{\mathrm{SCE}}$ reflects the re-oxidation reaction of $\mathrm{Cr}^{3+}$ to $\mathrm{Cr}^{6+}[40,41,46,47]$. The polarization curves, however, do not clearly show a distinct influence of Mo on the passive behavior. Thus, the $Z_{r e a l}^{\prime}$ value of the passive film was measured during the polarization [40-43]. 


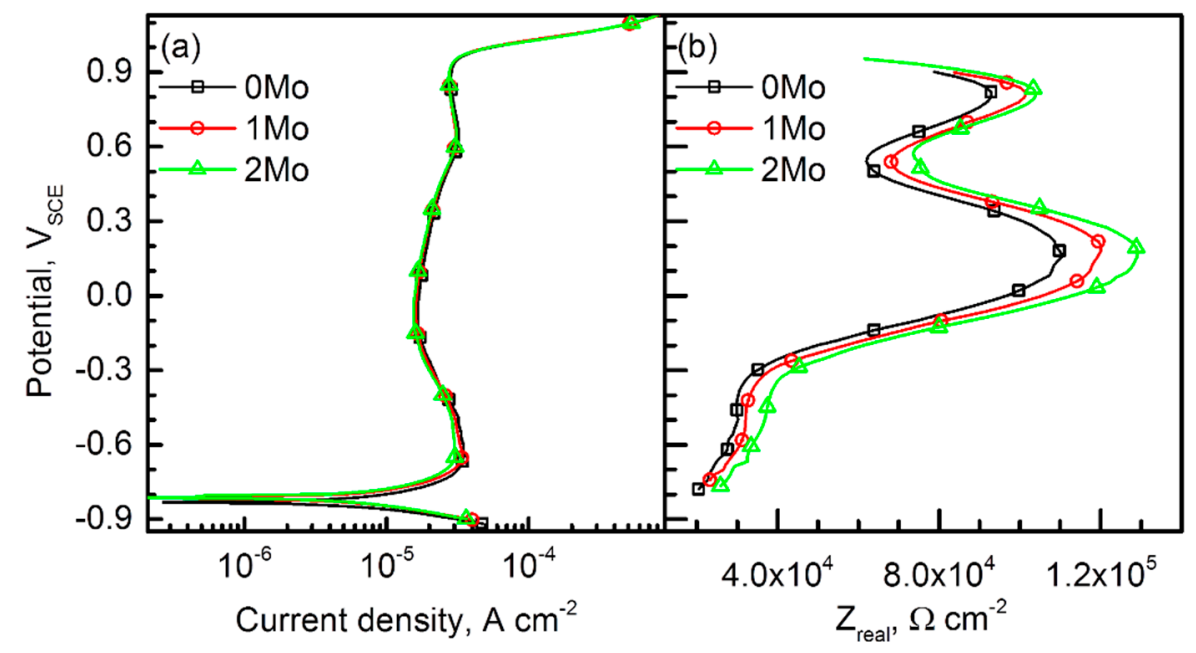

Figure 5. (a) Potentiodynamic polarization curves of $0 \mathrm{Mo}, 1 \mathrm{Mo}$, and $2 \mathrm{Mo}$ alloys measured in a borate-phosphate-citric buffer solution $(\mathrm{pH} 8.5)$ at $25^{\circ} \mathrm{C}(\mathrm{d} V / \mathrm{d} t=1 \mathrm{mV} / \mathrm{s})$. (b) Graphs of real part of the impedance $\left(Z^{\prime}\right.$ real $)$ versus applied potential of the alloys measured in the same solution by imposing sinusoidal voltage perturbation $( \pm 10 \mathrm{mV})$ at a frequency of $0.1 \mathrm{~Hz}$.

The graph of the measured $Z_{\text {real }}^{\prime}$ value versus the applied potential is presented in Figure $5 \mathrm{~b}$. In the three alloys, the $Z_{\text {real }}^{\prime}$ values at $E_{\text {corr }}$ are approximately $2.5 \times 10^{4} \Omega / \mathrm{cm}^{2}$, and it begin to steeply increase at approximately $-0.33 \mathrm{~V}_{\mathrm{SCE}}$. The maximum $Z^{\prime}$ real values of the three alloys are obtained at approximately $0.15 \mathrm{~V}_{\mathrm{SCE}}$, and those of $0 \mathrm{Mo}, 1 \mathrm{Mo}$, and $2 \mathrm{Mo}$ alloys are $1.10 \times 10^{5}, 1.19 \times 10^{5}$, and $1.28 \times 10^{5} \Omega / \mathrm{cm}^{2}$, respectively. Then the $Z^{\prime}$ real values decreased to $6.2-7.5 \times 10^{5} \Omega / \mathrm{cm}^{2}$ at $0.55 \mathrm{~V}_{\mathrm{SCE}}$, which is due to the re-oxidation reaction of $\mathrm{Cr}^{3+}$ to $\mathrm{Cr}^{6+}$ as mentioned above. Good correlation between Figure $5 \mathrm{a}, \mathrm{b}$ confirms that the $Z^{\prime}$ real -potential curve is useful to understand the polarization behavior more clearly. Figure $5 b$ obviously shows the influence of Mo on the passive behavior; that is, the alloying Mo in the HIAs improved the resistance to passive film in the entire passive potential range.

Investigation on the point defect density of the passive film can explain the change in the film resistance. The passive film generally contains a large number of point defects; thus, the passive film behaves as an extrinsic semiconductor $[48,49]$. The semiconductive parameters of the passive film such as point defect density and flat band potential can be obtained using the measurement of specific interfacial capacitance $\left(C_{\text {total }}\right)$ as a function of the applied potential $\left(E_{a p p}\right)$, that is, Mott-Schottky analysis [50-52]. The $C_{\text {total }}$ can be obtained using the relation of $C_{\text {total }}=1 / \varpi Z^{\prime \prime}{ }_{\text {imag, }}$, where $\varpi$ is the angular frequency and $Z^{\prime \prime}{ }_{\text {imag }}$ is the imaginary part of the specific impedance, and the $C_{\text {total }}$ is a series combination of the double layer capacitance (Helmholtz layer capacitance, $C_{H}$ ) and space charge layer capacitance $\left(C_{S C}\right)$. For n-type semiconductors, the relation between the $C_{S C}, C_{H}$, and $C_{\text {total }}$ values and applied potential $\left(E_{a p p}\right)$ is given as follows;

$$
\frac{1}{C_{S C}^{2}}=\frac{1}{C_{\text {total }}^{2}}-\frac{1}{C_{H}^{2}}=\left(\frac{2}{\varepsilon \varepsilon_{0} e N_{D}}\right)\left(E_{\text {app }}-E_{\mathrm{fb}}-\frac{\mathrm{\kappa}_{\mathrm{B}} T}{e}\right)
$$

where $\varepsilon_{0}$ is the vacuum permittivity $\left(8.85 \times 10^{14} \mathrm{~F} / \mathrm{cm}\right), \varepsilon$ is the dielectric constant of the passive film (taken as $15.6[5,41,51]), \mathrm{K}_{\mathrm{B}}$ is the Boltzmann constant $\left(1.38 \times 10^{-23} \mathrm{~J} / \mathrm{K}\right), N_{D}$ is a density of point defect (donor in this case), and $e$ is the electron charge $\left(1.60 \times 10^{-19} \mathrm{C}\right)$. In the Mott-Schottky relation, $C_{H}$ can be neglected, because it is sufficiently higher than the $C_{S C}$. In accordance with Equation (1), the reciprocal of the $C_{S C}{ }^{-2}$ and the $E_{a p p}$ exhibits a linear relationship, thus the $N_{D}$ in the space charge layer can be estimated from the slope of the graph of $C_{S C}{ }^{-2}$ versus $E_{a p p}$. 
Figure 6a shows Mott-Schottky plots for the passive films of the investigated HIAs, which were formed by applying a constant anodic potential of $0.85 \mathrm{~V}_{\mathrm{SCE}}$ for $3 \mathrm{~h}$ in the buffer solution. The Mott-Schottky plots of the HIAs exhibit two potential sections showing linear increase, region I (from -0.4 to $0 \mathrm{~V}_{\mathrm{SCE}}$ ) and region II (from 0.3 to $0.7 \mathrm{~V}_{\mathrm{SCE}}$ ). The dominant and detective point defects of the n-type passive film are oxygen vacancy $\left(V_{O^{2+}}\right.$, shallow donor) and $\mathrm{Cr}^{6+}$ (deep donor), and the shallow and deep donor densities can be calculated using the positive slopes $\left(\Delta C^{-2} / \Delta V\right)$ of the region I and II in the Mott-Schottky plot, respectively.
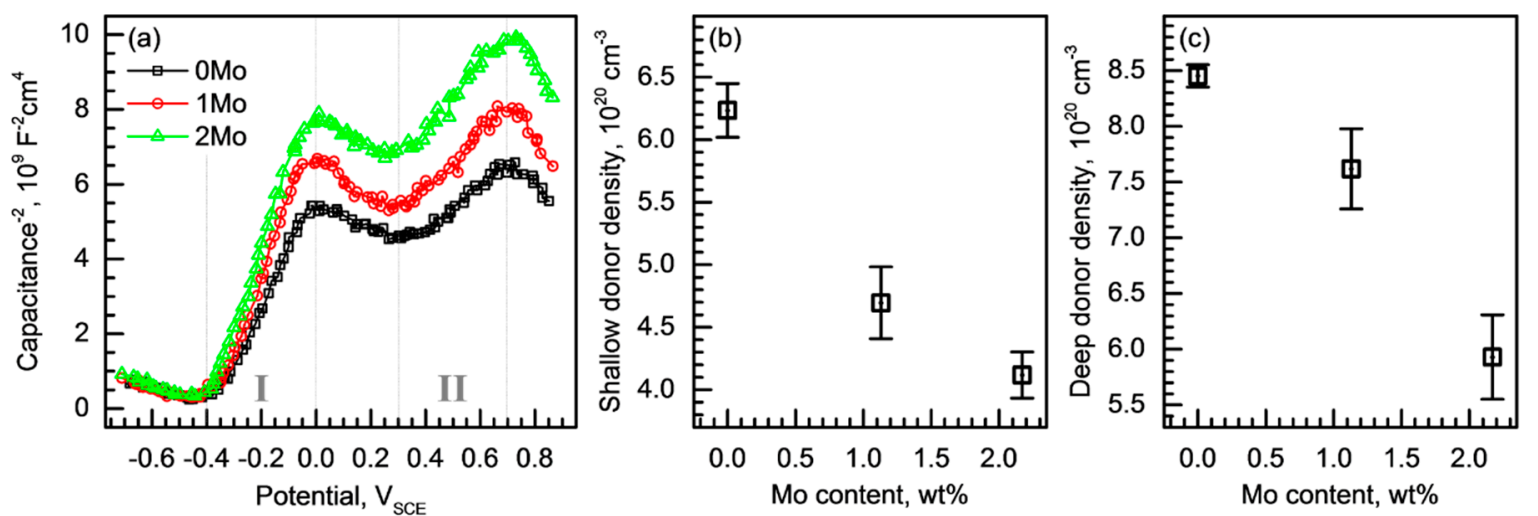

Figure 6. (a) Mott-Schottky plots of $0 \mathrm{Mo}, 1 \mathrm{Mo}$, and $2 \mathrm{Mo}$ alloys measured in a borate-phosphate-citric buffer solution ( $\mathrm{pH} 8.5)$ at $25{ }^{\circ} \mathrm{C}$ with decreasing applied potential by imposing sinusoidal voltage perturbation $( \pm 10 \mathrm{mV})$ at a frequency of $1000 \mathrm{~Hz}$. Average $(\mathbf{b})$ shallow donor $\left(V_{O^{2+}}\right)$ density and (c) deep donor $\left(\mathrm{Cr}^{6+}\right)$ density with standard deviation (scatter band) in the passive films of the alloys.

The average density values of the shallow and deep donors in the passive films formed on the 0Mo-2Mo alloys are presented in Figure 6b,c, respectively, as a function of the Mo content. Shallow donor density for 0 Mo alloy was $6.23 \times 10^{20} / \mathrm{cm}^{3}$, and that for the 2Mo alloy was $4.12 \times 10^{20} / \mathrm{cm}^{3}$. In addition, the deep donor densities for the 0 Mo and 2Mo alloys were $8.45 \times 10^{20}$ and $5.93 \times 10^{20} / \mathrm{cm}^{3}$, respectively. Figure $6 b, c$ shows that the numbers of both shallow and deep donors linearly decrease as the Mo content increases. Point defects in the passive film function as charge carriers; thus, Figure 6 well explains the increased resistance of the passive film by addition of Mo. It can be concluded that the improved resistance against pitting corrosion initiation of the investigated HIAs by alloying Mo (Figure $4 \mathrm{a}, \mathrm{c}$ ) is partly attributed to the formation of more resistant passive film with less point defects.

\subsection{General Corrosion Behavior}

Figure 7a shows the linear potentiodynamic polarization curves of the HIAs measured in $4 \mathrm{M}$ $\mathrm{NaCl}+0.01 \mathrm{M} \mathrm{HCl}(\mathrm{pH} 1.21)$ solution at $25{ }^{\circ} \mathrm{C}$. In this strongly acidic chloride solution, typical active-passive transition and pitting corrosion occurred during the polarization. Similar to Figure 4a, the $E_{\text {pit }}$ values obtained in this acidified $\mathrm{NaCl}$ solution also increased by addition of Mo (Figure $7 \mathrm{~b}$ ). More importantly, the polarization curves in Figure 7a demonstrate the change in the general corrosion behavior of the HIAs by addition of Mo. The average $E_{c o r r}$ values of the $0 \mathrm{Mo}, 1 \mathrm{Mo}$, and $2 \mathrm{Mo}$ alloys are $-0.667,-0.633$, and $-0.597 \mathrm{~V}_{\mathrm{SCE}}$, respectively (Figure $7 \mathrm{c}$ ), which increases with the Mo content. In this solution, metal dissolution actively occurred between the $E_{c o r r}$ and primary passive potential $\left(E_{p p}\right)$. The $E_{p p}$ of the alloys are gradually lowered from $-0.499 \mathrm{~V}_{\mathrm{SCE}}$ for $0 \mathrm{Mo}$ alloy to $-0.530 \mathrm{~V}_{\mathrm{SCE}}$ for $2 \mathrm{Mo}$ alloy. In addition, the critical anodic current density $\left(i_{\text {crit }}\right)$ values of $0 \mathrm{Mo}, 1 \mathrm{Mo}$, and $2 \mathrm{Mo}$ alloys are $13.09,2.71$, and $0.66 \mathrm{~mA} / \mathrm{cm}^{2}$, respectively, as shown in Figure $7 \mathrm{~d}$. To sum up, the alloying Mo raised the $E_{c o r r}$, reduced the $i_{c r i t}$, and lowered the $E_{p p}$ of the HIAs, thus it can be concluded that the alloying Mo made the HIA matrix noble and improved the general corrosion resistance. 

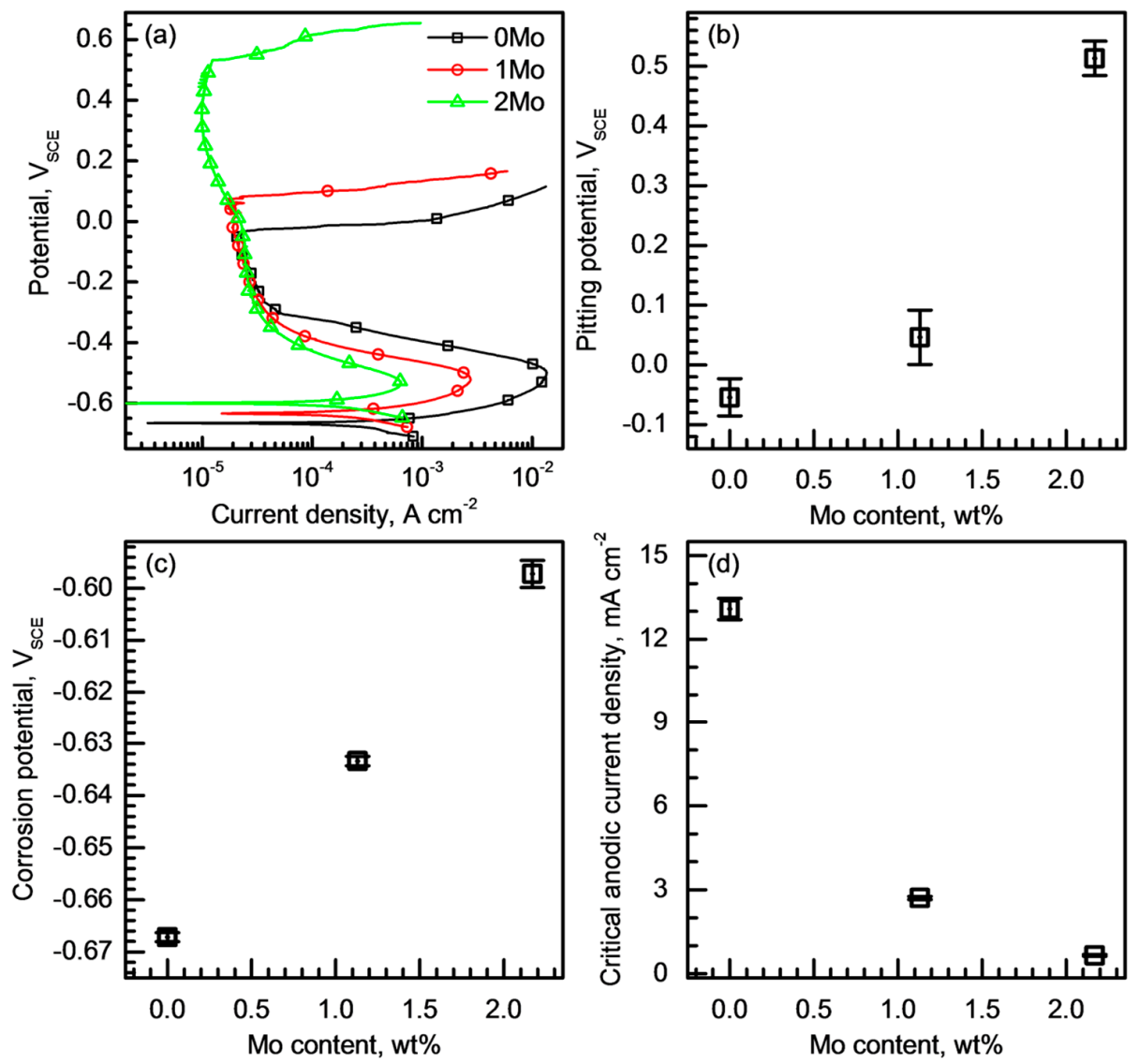

Figure 7. (a) Potentiodynamic polarization curves of $0 \mathrm{Mo}, 1 \mathrm{Mo}$, and $2 \mathrm{Mo}$ alloys measured in a $4 \mathrm{M}$ $\mathrm{NaCl}+0.01 \mathrm{M} \mathrm{HCl}$ solution at $25^{\circ} \mathrm{C}(\mathrm{d} V / \mathrm{d} t=1 \mathrm{mV} / \mathrm{s})$. Average $(\mathbf{b})$ pitting and (c) corrosion potentials, and (d) critical anodic current density values with standard deviation (scatter band) of the alloys.

The general corrosion resistance of the matrix can affect the pit propagation [19,21,41]. Inside the pit cavity formed in stainless steel, the confined chloride solution becomes acidified due to a hydrolysis of the metal ions [19], and the bare metal surface without a passive film is directly exposed to the acidified chloride solution. In this situation, general corrosion occurs on the bare matrix surface in the pit cavity. Therefore, the general corrosion behavior in the acidified $\mathrm{NaCl}$ solution shown in Figure 7 can reflect the matrix dissolution behavior inside the pit cavity. Since the Mo alloying induced the decrease in the $i_{c r i t}$ and $E_{p p}$, it is conceivable that the pit propagation rate is lowered and the pit extinction (that is, repassivation) is accelerated in the HIAs as the Mo content increases.

Figure $8 \mathrm{a}-\mathrm{c}$ shows the potentiodynamic polarization curves of the $0 \mathrm{Mo}, 1 \mathrm{Mo}$, and $2 \mathrm{Mo}$ alloys, respectively, measured in the acidified $4 \mathrm{M} \mathrm{NaCl}$ solutions with various solution $\mathrm{pHs}$. The $\mathrm{pH}$ values of the solutions were adjusted by addition of $\mathrm{HCl}$ ranging between $0.44(4 \mathrm{M} \mathrm{NaCl}+0.1 \mathrm{M} \mathrm{HCl})$ and $2.88(4 \mathrm{M} \mathrm{NaCl}+0.00043 \mathrm{M} \mathrm{HCl})$. For all the alloys, the $i_{\text {crit }}$ values increase as the solution is acidified. In the solution with $\mathrm{pH} 2.88$, the polarization curves of the three alloys do not show distinct active-passive transition, and the maximum anodic current density values (at approximately $-0.45 \mathrm{~V}_{\mathrm{SCE}}$ ) of the $0 \mathrm{Mo}, 1 \mathrm{Mo}$, and $2 \mathrm{Mo}$ alloys are $52.65,33.91$, and $24.45 \mu \mathrm{A} / \mathrm{cm}^{2}$, respectively, showing slight decrease along with the alloyed Mo content. On the other hand, in the solution with $\mathrm{pH} 0.44$, the $i_{\text {crit }}$ values of the alloys are as high as several tens of $\mathrm{mA} / \mathrm{cm}^{2}$, and the polarization curves exhibit typical active-passive transition. In the strongest acid, the average $i_{\text {crit }}$ values of the $0 \mathrm{Mo}, 1 \mathrm{Mo}$, and $2 \mathrm{Mo}$ alloys are $71.21,32.61$, and $11.50 \mathrm{~mA} / \mathrm{cm}^{2}$, respectively, which also decrease as the Mo content increases. 

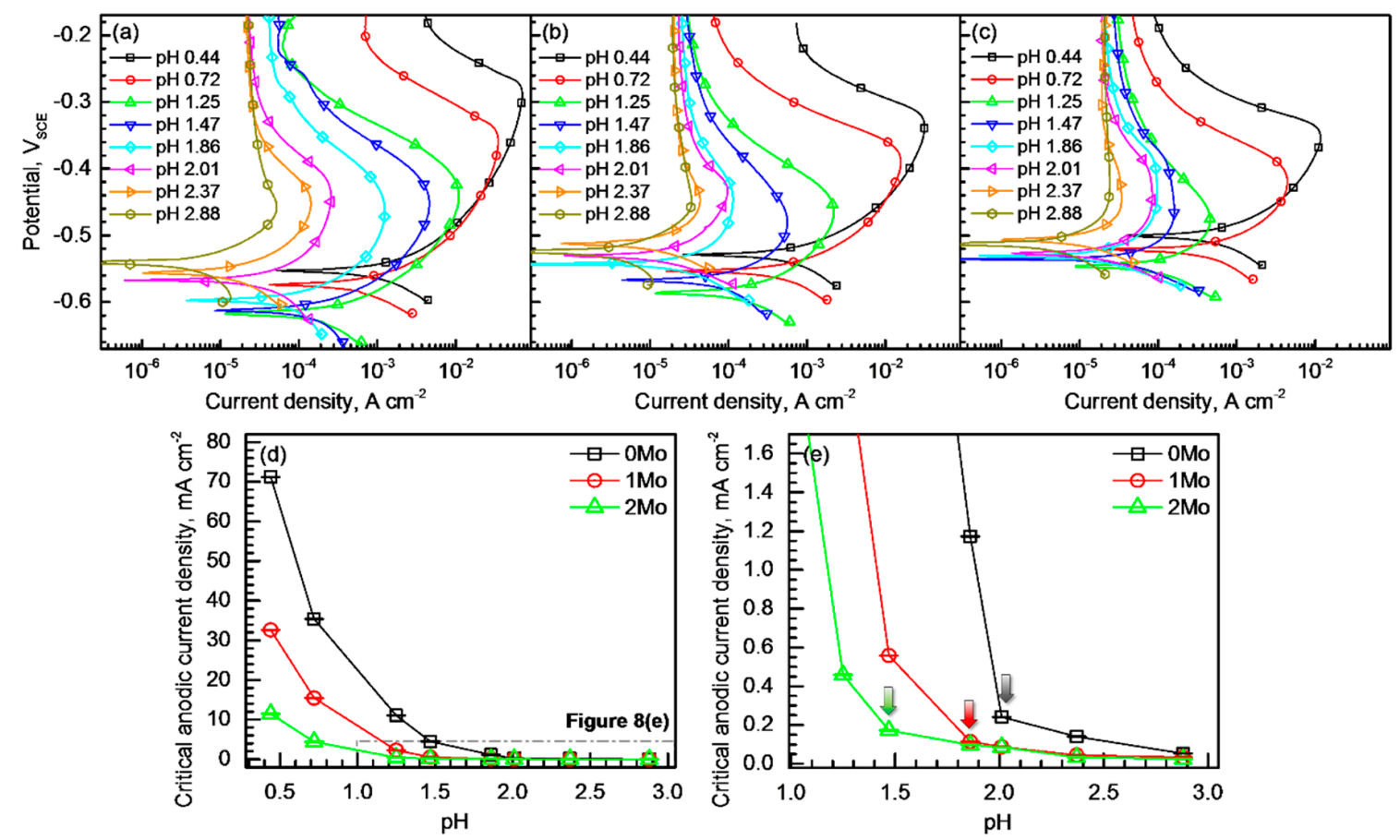

Figure 8. Potentiodynamic polarization curves of (a) $0 \mathrm{Mo}$, (b) $1 \mathrm{Mo}$, and (c) $2 \mathrm{Mo}$ alloys measured in $4 \mathrm{M}$ $\mathrm{NaCl}+\mathrm{HCl}$ solutions with different solution $\mathrm{pHs}$ of $0.44-2.88$ at $25^{\circ} \mathrm{C}(\mathrm{d} V / \mathrm{d} t=1 \mathrm{mV} / \mathrm{s})$. (d) Graphs of average critical anodic current density values with standard deviation (scatter band) of the alloys versus solution $\mathrm{pH}$. (e) A magnified part of graphs in Figure 7d.

For the three HIAs, the $i_{\text {crit }}$ values measured in each solution are plotted in Figure $8 \mathrm{~d}$ as a function of the solution $\mathrm{pH}$. The $i_{\text {crit }}$ steadily decreases as the $\mathrm{pH}$ increases, and the $0 \mathrm{Mo}$ alloy exhibits the highest $i_{\text {crit }}$ values in the entire $\mathrm{pH}$ range. In Figure $8 \mathrm{~d}$, the $\mathrm{pH}$ value at which the $i_{\text {crit }}$ value abruptly changed requires further attention. Figure 8e magnifies the part of Figure 8d ranging from $\mathrm{pH} 1$ to 3 . For 0 Mo alloy, the $i_{\text {crit }}$ value slightly increases in the range of $50-250 \mu \mathrm{A} / \mathrm{cm}^{2}$ as the solution $\mathrm{pH}$ decreases from 2.88 to 2.01 , but in the acidic solution with $\mathrm{pH}$ lower than 2 , the $i_{\text {crit }}$ abruptly increases to $1.17 \mathrm{~mA} / \mathrm{cm}^{2}$. For $1 \mathrm{Mo}$ alloy, the $i_{\text {crit }}$ value also negligibly increases with decrease in the solution $\mathrm{pH}$ in the $\mathrm{pH}$ range of $1.86-2.88$, but it begins to rapidly increases at the $\mathrm{pH}$ lower than 1.47 . In the $2 \mathrm{Mo}$ alloy, the rapid increase in the $i_{\text {crit }}$ is observed in the solution with $\mathrm{pH}$ lower than 1.25 . The $\mathrm{pH}$ values at which the abrupt increase in the $i_{\text {crit }}$ begins are marked with arrows in Figure 8e. This result demonstrates that the HIA with lower Mo is more likely to undergo active dissolution even in less acidified chloride solution inside the pit, thus even the small pits tend to grow more easily to stable pits. The results obtained Figures 7 and 8 simultaneously indicate that the elevated $E_{r p}$ and the decreased $\Delta\left(E_{p i t}-E_{r p}\right)$ value by addition of Mo shown in Figure $4 \mathrm{~b}$,d are due to the lowered pit propagation rate and accelerated repassivation kinetics by addition of Mo. In addition, because the alloying Mo imparts a higher resistance to active dissolution in a stronger acid solution, the pit embryos become more difficult to grow in the alloy with higher Mo content, which consequently leads to increase in the $E_{\text {pit }}$.

Based on the findings of this investigation, it can be concluded that the alloying Mo is effective to improve the corrosion properties of Fe-based $18 \mathrm{Cr} 10 \mathrm{Mn} 0.4 \mathrm{~N} 0.5 \mathrm{C}(0-2.17) \mathrm{Mo}$ (in wt \%) alloys. The literature presents examples of pitting corrosion of UNS S30400 and/or S31603 alloys in various chloride solutions [1,5,6,53-56]. Thus, in aqueous environments containing $\mathrm{Cl}^{-}$, it can be considered to replace UNS S30400 and/or S31603 alloys by usage of the Ni-free Fe-based $18 \mathrm{Cr} 10 \mathrm{Mn} 0.4 \mathrm{~N} 0.5 \mathrm{C}(0-2.17) \mathrm{Mo}$ (in wt \%) alloys especially 2Mo grade, which presents superior pitting corrosion resistance. 


\section{Conclusions}

For Fe-based 18Cr10Mn0.4N0.5C(0-2.17)Mo (in wt \%) HIAs, the effects of Mo on pitting corrosion resistance and the improvement mechanism were investigated. The investigated alloys have been patented due to their corrosion resistance and mechanical properties, which are superior to commercial austenitic stainless steels such as UNS S30400 and S31603. The following points summarize the findings of this research.

(1) Potentiodynamic polarization tests in chloride solutions revealed that the alloying Mo suppressed metastable pitting corrosion and raised both $E_{p i t}$ and $E_{r p}$ of the alloys. In addition, it was found that the difference between the $E_{p i t}$ and $E_{r p}$ decreased as the Mo content increased.

(2) Passive film analysis through a resistance measurement and Mott-Schottky analysis indicated that the alloyed Mo increased the film resistance by decreasing the number of point defects in the passive film.

(3) The alloyed Mo reduced the critical dissolution rate of the alloys in acidified chloride solutions, and the alloy with higher Mo content was able to resist active dissolution in stronger acid.

(4) It is concluded that the alloying Mo enhanced pitting corrosion resistance of the alloy through increasing protectiveness of passive film and lowering pit propagation rate.

Author Contributions: Conceptualization, H.-Y.H. and T.-H.L.; Methodology, H.-Y.H. and T.-H.L.; Investigation, H.-Y.H., T.-H.L., J.-H.B. and D.W.C.; Validation, J.-H.B. and D.W.C.; Writing-Original Draft Preparation, H.-Y.H. and J.-H.B.; Writing-Review \& Editing, D.W.C. and T.-H.L.

Funding: This study was financially supported by Fundamental Research Program (grant number: PNK5850) of the Korea Institute of Materials Science (KIMS). This study also supported by the Ministry of Trade, Industry \& Energy (MI, Korea) under Strategic Core Materials Technology Development Program (No. 10067375).

Conflicts of Interest: The authors declare no conflicts of interest.

\section{References}

1. Thomann, U.I.; Uggowitzer, P.J. Wear-corrosion behavior of biocompatible austenitic stainless steels. Wear 2000, 239, 48-58. [CrossRef]

2. Gavrilyuk, V.G.; Berns, H. High-strength Austenitic Stainless Steels. Met. Sci. Heat Treat. 2007, 49, 566-568. [CrossRef]

3. Rawers, J.C. Alloying effects on the microstructure and phase stability of Fe-Cr-Mn steels. J. Mater. Sci. 2008, 43, 3618-3624. [CrossRef]

4. Gavriljuk, V.G.; Shanina, B.D.; Berns, H. A physical concept for alloying steels with carbon + nitrogen. Mater. Sci. Eng. 2008, 481-482, 707-712. [CrossRef]

5. Ha, H.-Y.; Lee, T.-H.; Oh, C.-S.; Kim, S.-J. Effects of combined addition of carbon and nitrogen on pitting corrosion behavior of Fe-18Cr-10Mn alloys. Scr. Mater. 2009, 61, 121-124. [CrossRef]

6. Ha, H.-Y.; Lee, T.-H.; Oh, C.-S.; Kim, S.-J. Effects of carbon on the corrosion behaviour in Fe-18Cr-10Mn-N-C stainless steels. Steel Res. Int. 2009, 80, 488-492.

7. Lee, T.-H.; Shin, E.; Oh, C.-S.; Ha, H.-Y.; Kim, S.-J. Correlation between stacking fault energy and deformation microstructure in high-interstitial-alloyed austenitic steels. Acta Mater. 2010, 58, 3173-3186. [CrossRef]

8. Schymura, M.; Stegemann, R.; Fischer, A. Crack propagation behavior of solution annealed austenitic high interstitial steels. Int. J. Fatigue 2015, 79, 25-35. [CrossRef]

9. Seifert, M.; Siebert, S.; Huth, S.; Theisen, W.; Berns, H. New Developments in Martensitic Stainless Steels Containing C + N. Steel Res. Int. 2015, 86, 1508-1516. [CrossRef]

10. Niederhofer, P.; Richrath, L.; Huth, S.; Theisen, W. Influence of conventional and powder-metallurgical manufacturing on the cavitation erosion and corrosion of high interstitial CrMnCN austenitic stainless steels. Wear 2016, 360-361, 67-76. [CrossRef]

11. Gavriljuk, V.G.; Berns, H. High Nitrogen Steels, 1st ed.; Springer: Berlin, Germany, 1999; Chapter 1-2.

12. Levey, P.R.; van Bennekom, A. A mechanistic study of the effects of nitrogen on the corrosion properties of stainless steels. Corrosion 1995, 51, 911-921. [CrossRef] 
13. Jargelius-Pettersson, R.F.A. Electrochemical investigation of the influence of nitrogen alloying on pitting corrosion of austenitic stainless steels. Corros. Sci. 1999, 41, 1639-1664. [CrossRef]

14. Ha, H.-Y.; Lee, T.-H.; Kim, S.-J. Effect of $C$ fraction on corrosion properties of high interstitial alloyed stainless steels. Metall. Mater. Trans. A 2012, 43, 2999-3005. [CrossRef]

15. Speidel, M.O. Nitrogen containing austenitic stainless steels. Mater. Sci. Eng. Technol. 2006, 37, 875-880. [CrossRef]

16. Lee, T.-H.; Kim, S.-J.; Oh, C.-S.; Ha, H.-Y. High Strength and High Corrosion Coal Nitrogen Combined Addition Austenitic Stainless Steel and a Manufacturing Method Thereof (In Japanese). Patent JP 5272078 B2, 17 May 2013.

17. Lee, T.-H.; Kim, S.-J.; Oh, C.-S.; Ha, H.-Y. High Strength/Corrosion Resistant Austenitic Stainless Steel with Carbon-Nitrogen Complex Additive, and Method for Manufacturing Same. Patent EP 2455508 B1, 23 November 2016.

18. Lo, K.H.; Shek, C.H.; Lai, J.K.L. Recent developments in stainless steels. Mater. Sci. Eng. 2009, 65, 39-104. [CrossRef]

19. Frankel, G.S. Pitting Corrosion of Metals-A Review of the Critical Factors. J. Electrochem. Soc. 1998, 145, 2186-2198. [CrossRef]

20. Newman, R.C. The dissolution and passivation kinetics of stainless alloys containing molybdenum-1. Coulometric studies of Fe-Cr and Fe-Cr-Mo alloys. Corros. Sci. 1985, 25, 331-339. [CrossRef]

21. Newman, R.C. The dissolution and passivation kinetics of stainless alloys containing molybdenum-II. Dissolution kinetics in artificial pits. Corros. Sci. 1985, 25, 341-350. [CrossRef]

22. Kaneko, M.; Isaacs, H.S. Effects of molybdenum on the pitting of ferritic- and austenitic-stainless steels in bromide and chloride solutions. Corros. Sci. 2002, 44, 1825-1834. [CrossRef]

23. Villanueva, D.M.E.; Junior, F.C.P.; Plaut, R.L.; Padilha, A.F. Comparative study on sigma phase precipitation of three types of stainless steels: austenitic, superferritic and duplex. Mater. Sci. Technol. 2006, 22, 1098-1104. [CrossRef]

24. Sourmail, T. Precipitation in creep resistant austenitic stainless steels. Mater. Sci. Technol. 2001, 17, 1-14. [CrossRef]

25. Weiss, B.; Stickler, R. Phase Instabilities During High Temperature Exposure of 316 Austenitic Stainless Steel. Metall. Mater. Trans. B 1972, 3, 851-866. [CrossRef]

26. Sugimoto, K.; Sawada, Y. The role of molybdenum additions to austenitic stainless steels in the inhibition of pitting in acid chloride solutions. Corros. Sci. 1977, 17, 425-445. [CrossRef]

27. Hashimoto, K.; Asami, K.; Teramoto, K. An X-ray photo-electron spectroscopic study on the role of molybdenum in increasing the corrosion resistance of ferritic stainless steels in HCl. Corros. Sci. 1979, 19, 3-14. [CrossRef]

28. Clayton, C.R.; Lu, Y.C. A Bipolar Model of the Passivity of Stainless Steel: The Role of Mo Addition. J. Electrochem. Soc. 1986, 133, 2465-2473. [CrossRef]

29. Landolt, D.; Mischler, S.; Vogel, A.; Mathieu, H.J. Chloride Ion Effects on Passive Films on FeCr and FeCrMo Studied by AES, XPS and SIMS. Corros. Sci. 1990, 31, 431-440. [CrossRef]

30. Montemor, M.F.; Simoes, A.M.P.; Ferreira, M.G.S.; Da Cunha Belo, M. The role of Mo in the chemical composition and semiconductive behaviour of oxide flms formed on stainless steels. Corros. Sci. 1999, 41, 17-34. [CrossRef]

31. Ilevbare, G.O.; Burstein, G.T. The role of alloyed molybdenum in the inhibition of pitting corrosion in stainless steels. Corros. Sci. 2001, 43, 485-513. [CrossRef]

32. Bastidas, J.M.; Torres, C.L.; Cano, E.; Polo, J.L. Influence of molybdenum on passivation of polarised stainless steels in a chloride environment. Corros. Sci. 2002, 44, 625-633. [CrossRef]

33. Tobler, W.J.; Vertanen, S. Effect of Mo species on metastable pitting of Fe18Cr alloys-A current transient analysis. Corros. Sci. 2006, 48, 1585-1607. [CrossRef]

34. Li, D.G.; Wang, J.D.; Chen, D.R.; Liang, P. Molybdenum addition enhancing the corrosion behaviors of $316 \mathrm{~L}$ stainless steel in the simulated cathodic environment of proton exchange membrane fuel cell. Int. J. Hydrogen Energy 2015, 40, 5947-5957. [CrossRef]

35. Loable, C.; Vicosa, I.N.; Mesquita, T.J.; Mantel, M.; Nogueira, R.P.; Berthome, G.; Chauveau, E.; Roche, V. Synergy between molybdenum and nitrogen on the pitting corrosion and passive film resistance of austenitic stainless steels as a pH-dependent effect. Mater. Chem. Phys. 2017, 186, 237-245. [CrossRef] 
36. Mesquita, T.J.; Chauveau, E.; Mantel, M.; Nogueira, R.P. A XPS study of the Mo effect on passivation behaviors for highly controlled stainless steels in neutral and alkaline conditions. Appl. Surf. Sci. 2013, 270, 90-97. [CrossRef]

37. Vignal, V.; Olive, J.M.; Desjardins, D. Effect of molybdenum on passivity of stainless steels in chloride media using ex situ near field microscopy observations. Corros. Sci. 1999, 41, 869-884. [CrossRef]

38. Mesquita, T.J.; Chauveau, E.; Mantel, M.; Kinsman, N.; Roche, V.; Nogueira, R.P. Lean duplex stainless steels-The role of molybdenum in pitting corrosion of concrete reinforcement studied with industrial and laboratory castings. Mater. Chem. Phys. 2012, 132, 967-972. [CrossRef]

39. Olsson, C.-O.A. The influence of nitrogen and molybdenum on passive films formed on the austenoferritic stainless steel 2205 studied by AES and XPS. Corros. Sci. 1995, 37, 467-479. [CrossRef]

40. Ha, H.-Y.; Lee, T.-H.; Kim, S.-J. Role of nitrogen in the active-passive transition behavior of binary $\mathrm{Fe}-\mathrm{Cr}$ alloy system. Electrochim. Acta 2012, 80, 432-439. [CrossRef]

41. Ha, H.-Y.; Jang, M.-H.; Lee, T.-H. Influences of Mn in solid solution on the pitting corrosion behaviour of Fe-23 wt. \%Cr-based alloys. Electrochim. Acta 2016, 191, 864-875. [CrossRef]

42. Krakowiak, S.; Darowicki, K.; Slepski, P. Impedance investigation of passive 304 stainless steel in the pit pre-initiation state. Electrochim. Acta 2005, 50, 2699-2704. [CrossRef]

43. Nagarajan, S.; Rajendran, N. Crevice corrosion behaviour of superaustenitic stainless steels: Dynamic electrochemical impedance spectroscopy and atomic force microscopy studies. Corros. Sci. 2009, 51, 217-224. [CrossRef]

44. American Society for Testing and Materials (ASTM). ASTM A276-06, Standard Specification for Stainless Steel Bars and Shapes; ASTM: West Conshohocken, PA, USA, 2016.

45. Ha, H.-Y.; Kwon, H.-S. Effects of pH levels on the surface charge and pitting corrosion resistance of Fe. J. Electrochem. Soc. 2012, 159, C416-C421. [CrossRef]

46. Piao, T.; Park, S.-M. Spectroelectrochemical studies of passivation and transpassive breakdown reactions of stainless steel. J. Electrochem. Soc. 1997, 144, 3371-3377. [CrossRef]

47. Cho, E.A.; Kwon, H.S.; Macdonald, D.D. Photoelectrochemical analysis on the passive film formed on Fe-20Cr in pH 8.5 buffer solution. Electrochim. Acta 2002, 47, 1661-1668. [CrossRef]

48. Macdonald, D.D. The Point Defect Model for the Passive State. J. Electrochem. Soc. 1992, 139, 3434-3449. [CrossRef]

49. Macdonald, D.D. The history of the Point Defect Model for the passive state: A brief review of film growth aspects. Electrochim. Acta 2011, 56, 1761-1772. [CrossRef]

50. Dean, M.H.; Stimming, U. The electronic properties of disordered passive films. Corros. Sci. 1989, 29, $199-211$. [CrossRef]

51. Fattah-alhosseini, A.; Vafaeian, S. Comparison of electrochemical behavior between coarse-grained and fine-grained AISI 430 ferritic stainless steel by Mott-Schottky analysis and EIS measurements. J. Alloy. Compd. 2015, 639, 301-307. [CrossRef]

52. Ahn, S.J.; Kwon, H.S. Effects of solution temperature on electronic properties of passive film formed on Fe in pH 8.5 borate buffer solution. Electrochim. Acta 2004, 49, 3347-3353. [CrossRef]

53. Sedek, P.; Brozda, J.; Gazdowicz, J. Pitting corrosion of the stainless steel ventilation duct in a roofed swimming pool. Eng. Fail. Anal. 2008, 15, 281-286. [CrossRef]

54. Szala, M.; Beer-Lech, K.; Walczak, M. A study on the corrosion of stainless steel floor drains in an indoor swimming pool. Eng. Fail. Anal. 2017, 77, 31-38. [CrossRef]

55. Alfonsson, E.; Mameng, S.H. The possibilities \& limitations of austenitic and duplex stainless steels in chlorinated water systems. Nucl. Exch. 2012, 30-34.

56. Olsson, J.; Snis, M. Duplex-A new generation of stainless steels for desalination plants. Desalination 2007, 205, 104-113. [CrossRef]

(C) 2018 by the authors. Licensee MDPI, Basel, Switzerland. This article is an open access article distributed under the terms and conditions of the Creative Commons Attribution (CC BY) license (http://creativecommons.org/licenses/by/4.0/). 